\title{
MERCADOLOGIA
}




\section{STATUS CONSUMPTION: DOES IT MATTER FOR BRAZILIAN YOUNG ADULTS?}

CONSUMO DE STATUS:

O STATUS IMPORTA AOS JOVENS ADULTOS BRASILEIROS?

Ivanete Schneider Hahn

Universidade Alto Vale do Rio do Peixe

Flavia Luciane Scherer

Universidade Federal de Santa Maria

Laleska Lebioda

Universidade do Estado de Santa Catarina
Data de submissão: 20 mai. 20 | 8. Data de aprovação:

I5 set. 2018. Sistema de avaliação: Double blind review.

Universidade FUMEC / FACE. Prof. Dr. Henrique Cordeiro

Martins. Prof. Dr. Cid Gonçalves Filho.

\section{ABSTRACT}

The changes in consumption behavior of Brazilians are the scope of many studies in the last years. However, some common managerial assumptions, as an example, that Brazilian young adults have a status consumption, lack enough empirical studies to explain or support these generalizations. Therefore, this study was designed to investigate the Brazilian young adults' status consumption behavior. So, we outlined a multimethod research, through a survey with 548 Brazilian young adults and a confirmatory focus group with eight young adults. The results showed that: (I) Brazilian young adults do not recognize themselves as status consumers, even though they are; (2) the consumption-oriented to have status is not related to goods, but to experiences; and, (3) the motivations driving young adults to have status consumption in Brazil are high social recognition function and, consumption driven by a tangible component (quality) and an intangible component (brand).

\section{KEYWORDS}

Status. Conspicuous Consumption. Young Adults. Brand. Quality. 


\section{RESUMO}

As mudanças no comportamento dos consumidores brasileiros são tema de diversas pesquisas conduzidas nos últimos anos. Contudo, algumas suposições comuns, à exemplo de que os jovens adultos brasileiros têm comportamentos de consumo por status, não possuem evidências empíricas suficientes para suportar as generalizações sobre esse público. Assim, este estudo destinou-se a investigar os hábitos de consumo de status de jovens adultos brasileiros, por meio de uma pesquisa multimétodos. Na primeira etapa da pesquisa, procedeu-se uma survey com 548 jovens adultos brasileiros. Na segunda etapa, que assumiu uma face confirmatória, fez-se um grupo focal com oito jovens adultos. Os resultados mostram que: $(I)$ jovens adultos brasileiros não assumem seus hábitos de consumo de status, mesmo quando possuem o comportamento; (2) grande parte do consumo de status da amostra não se refere à produtos, mas à experiências de consumo; e, (3) as principais motivações da amostra para o consumo de status referem-se ao reconhecimento social gerado pelo consumo de produtos e serviços de status, impulsionados por um componente tangível (qualidade) e um componente intangível (marca).

\section{PALAVRAS-CHAVE}

Status. Consumo conspícuo. Jovens Adultos. Marca. Qualidade.

\section{INTRODUCTION}

The status consumption is "the motivational process by which individuals strive to improve their social standing through conspicuous consumption of consumer products that confer or symbolize status both to the individual and others" (EASTMAN et al., 1999, p. 4I). So, "the more a consumer seeks status, the more he/she will engage in certain behaviors, such as the consumption of status symbols, that increases their status" (EASTMAN et al., 1999, p. 3). Although the demand of status is a universal human motivation, the status consumption refers to a specific market target (O'CASS; FROST, 2002).

The status consumption behavior has a high dynamism that can be explained by the high profitability and this, in turn, can be explained in part by the high price of products, perceived as symbol of status by consumers. The high price of products enables retailers to have attractive margins, noting that these are an exclusive or selective distribution channel (DEETER-SCHMELZ et al., 2000). However, status products have become more sophisticated and subtle, and so, not just in terms of conspicuous but also in symbolic meanings (TRIGG, 200I).

Moreover, people in emerging countries are increasingly more educated and are enjoying well-paid occupations, higher income, and stronger spending power (KAMAKURA; MAZZON, 20I3; NABI et al., 20I9; O'CASS; SIAHTIRI, 20I4). These socioeconomic changes in emerging markets have accelerated consumption, because individuals' tendency to consume status 
products to display their wealth and new lifestyle is rising (NABI et al., 2019).

The younger consumers, however, do not limit the conspicuous products to the upper classes (KASTANAKIS; BALABANIS, 20I2). The literature show that the younger generations are more open to new concepts of status products, such as luxury restaurants/cafes, as means of self-expression or symbols of their desired lifestyle (PHAU; CHEONG, 2009; O'CASS; SIAHTIRI, 20I3; KIM; JANG, 20I4).

In Brazil, the status products market target is getting attention from several international players that are seeking the exploitation of this segment (STREHLAU; ARANHA, 2004), which allowed access to luxury products and services for people (KASTANAKIS; BALABANIS, 20I2). Some common managerial and academic assumptions provide that young adults prefer to spend money on status because they need to be socially accepted, something that conspicuous products provide (EASTMAN et al., 1999). Those born between 1977 and 1994 (PAUL, 200 I; KIM; JANG, 20I4), has been socialized in a materialistic society (BAKEWELL; MITCHELL, 2003). Therefore, they are more driven to status consumption as a means of displaying wealth and purchasing power (O'CASS; FROST, 2002; NABI et al., 2019).

In general, there is a growing background of literature about conspicuous or status consumption (ALMEIDA et al., 2016; LUBECK et al., 20I4; SANTINI et al., 2016; SANTINI et al., 2016; COELHO et al., 20I7; COSTA et al., 2018) but it is not known the motivations that drive young consumers to pursue conspicuous products and services. So, this study was designed to understand Brazilian young adult's status consumption behavior.
To achieve this goal, we proceeded a multimethod study, in a descriptive and confirmatory perspective. In the first step, we did a survey with Brazilian young adults, between 18 and 38 years old $(n=548)$. The results showed a different perspective about the status consumption, and so, we proceeded a confirmatory step through a focus group ( $\mathrm{n}=8$ young adults) to understand this behavior. With this study, we extend the literature about status consumption, exploring the Brazilian young adults. Also, we have important insights about status consumption behavior for companies seeking to explore this segment in Brazil.

The article is organized in five sections. Starting the introduction, we have the presentation of the research problem. Then, we look for some literature to support the methodological aspects of the study. We present the results, the main discussions, managerial and academic implications. The last section presents the conclusions, study limitations, and future research suggestions.

\section{THE STATUS CONSUMPTION}

Social status demonstration can be considered as a dimension of conspicuous consumption (MARCOUX et al., 1997). The conspicuous consumption is related to the need that people must show the wastage as if it was an indicator of financial well-being, a way to be distinguished and the appearance to be more stable in relation to the others (VEBLEN, 1983; O'CASS; FROST, 2002; NABI et al., 2019).

Materialism is an exaggerated belief in the importance of goods in one's life. One of the most important aspects of materialism seems to be status consumption; that is, buying goods for the status they confer (TATZEL, 2002). Literature presents 
some evidences that materialism is associated with consumption-relevant behaviors and attitudes like image and status values (KASSER, 20I6; FLYNN et al., 20I6).

So, materialism behavior - when the consumer buys products beyond their actual need, without the emphasis on the instrumental value of them - inspire consumers to buy famous brands. Their main concern is the status that the product or service will give through the acquisition (EASTMAN et al., 1999) to achieve happiness and it can be used in the same criteria to evaluate their success and the others (RICHINS, I991).

There is a tangible component in the luxury consumption (price, aesthetics, quality) and an intangible component (the meaning embedded in the object, which is not the object itself) (STREHLAU; ARANHA, 2004). Consequently, the brand characterizes much of the intangible component, adding a dimension that sets them apart from other products that satisfy the same need. The luxury brand is derived from a low relationship between functional utility and price, and high ratio of intangible utility (or situational) and price (STREHLAU; ARANHA, 2004).

The status symbols should be socially desirable and limited. When luxury becomes accessible to a large population, it loses some of its high social recognition function (BERRY, 1994). Thus, the higher the reproduction or accessibility of signs and images that denote luxury, the greater the loss of their status symbol character. The authors explain also that there is a paradox in the marketing of luxury goods, because when the dream purchase becomes true, the special distinction is diluted and often moves to another object of desire.
This way, the desire that the consumer feel in owning status, is more constant than the products that represent the status itself. Even as the products change, the interest in acquiring them because they are status symbols, remains. Therefore, it is vital that companies identify which is the customer tendency to consume status in order to predict behaviors of empathy with the subliminal messages of the brand (STREHLAU; ARANHA, 2004).

All these components of status consumption were analyzed by Eastman et al. (1999) and they validate a scale to measure status consumption, based in three latent variables: Status, Sociability and Functionality.

At the same time, the special meanings that consumers attach to brands generate a network connection between the brand and the mental image that the consumer has of itself. So, the consumer seeks to meet their goals, whether is the propagation of their self-image or even recognition in a distinct group (NIADA; BAPTISTA, 20I3).

The image of luxury brands as a quality benchmark is also determinant in the purchase decision, consumers feel more confident to make a purchase, even if the price is higher. Carvalho and Mesquita (2009) suggest that when the perception of the consumer is tied to a desire, an innovative, modern or beautiful design, the act of buying becomes more stimulating. These authors explain that the image of a brand is more referenced than the intrinsic characteristic of the good, so the consumer would seek to get something beyond the product itself, usually the rewards coming from the feel of personal satisfaction that the purchase can provide. 


\section{THE YOUNG ADULTS STATUS CONSUMPTION BEHAVIOR}

Longitudinal studies on young consumers show an increase in the strength of materialistic values (e.g. ROBERTS et al., 2005) and the recent global financial crisis is, at least partly, is attributable to excessive consumerism and rampant spending (SCHNEIDER; KIRCHGASSNER, 2009).

Kastanakis and Balabanis (20/2) explain that for modern consumers, conspicuous products are no longer limited to the upper classes. As the income has increased, a larger number of people have access to conspicuous products. In that way, conspicuous products have become more sophisticated and subtle, not just in terms of ostentation but also in symbolic meaning (TRIGG, $200 \mathrm{I}$ ), and the younger generations seem to be more open to new concepts of conspicuous products (PHAU; CHEONG, 2009; O'CASS; SIAHTIRI, 20I3; KIM;JANG, 20I4). As example, Gen $Y$ consumers go to upscale cafés not only for the high quality of coffee but are also motivated by social standings (KIM;JANG, 20I4). Compared to Gen X or Baby Boomers, the Gen $Y$ cohort has the highest level of motivation to consume for status (EASTMAN; LIU, 20I2). Also, for status consumers, price is commonly used as an indicator of quality and exclusivity (DUBOIS; DUQUESNE, 1993).

Few studies were conducted with Brazilians in the last years, even that status consumption is an interesting empirical phenomenon, especially because Brazil, in the last years, increased people located in the middle and high class.Also, as described by Strehlau and Aranha (2004) Brazil is getting attention from several international players that are seeking to explore Brazil status and luxury segment.
The studies performed in Brazil about status consumption refer to personal financial planning with lawyers - who feel respected by the status conferred by conspicuous products (VILAIN; PEREIRA, 20I3). Ponte and Mattoso (20 I4) show that the consumption of cultural products was essential for building status strategies and cultural capital was determinant in choosing these products. Santini et al. (2016) present a discussion about monetary and non- monetary promotion acting as moderators in brand awareness and predisposition to conspicuous consumption with Brazilian costumers. Other studies look for specific market targets or than just discuss the status consumption theory.

From these evidences, it is possible for us to develop an empirical effort to explore more the Brazilians' status consumption, focused on young adults - as presented in the next section.

\section{RESEARCH PROCEEDINGS}

Two studies were conducted in this paper: the first one was a cross-sectional survey, and the second one was conducted as a confirmatory step, through a focus group. Both studies are described below.

\section{Survey proceedings}

The first study has a quantitative approach, performed to understand and classify dynamic processes experienced by social groups (PRODANOV; FREITAS, 2009) through a survey, which enables to employ the analysis and description of a population-based sample (BAKER, 200I).

This research focused on Brazilian young adults' behavior. This group is characterized in different ways in literature, mainly used as people between $2 \mathrm{I}$ and 38 years old. 
However, adulthood in Brazil is 18 years, and, we considered that we have a delay of some behaviors as compared to developed countries, where most studies are carried out. So, we investigated young adults characterized by the age between 18 and 38 years old, who live in the South of Brazil as a way to control external variable - the group is under a local culture, policy's and similar academic background.

The choice of the sample did not follow probabilistic method; it was considered the number of returned questionnaires, that is, 630 questionnaires. The application of the research for this population was performed by an online questionnaire. The invitation to participate was sent through the authors networks, collecting data through the collection method called snowball - as recommended in Wha (1994).

The questionnaire had two parts: (I) respondents' profile: questions regarding age, gender, and marital status and (2) status consumption: measured by 13 observable variables contained in three latent variables (status, sociability, and functionality), using a Likert scale. The status consumption scale is based on Eastman, Goldsmith e Flynn (1999) study, but we adapted the version as proposed by Strehlau and Aranha (2004).

The data were analyzed using SPSS Statistics 2 I (IBM software). First, we proceeded the data matrix preparation. So, missing values were identified by a simple frequency distribution, replacing the missing values by the average of the series. The outliers were identified by calculating Mahalanobis distance and all outliers were excluded from the sample. Analysis of normality was verified using the Kolmogorov-Smirnov test and no abnormal variables were observed. So, the final sample is 548 respondents. The sample has an average of 25 years old (between 18 and 38 years' old), most respondents are female $(52 \%)$ and, in general, they have undergraduate or graduate degree.

\section{Focus group proceedings}

The second study has a confirmatory approach and was performed by a focus group with eight young adults. The focus group was based on the idea that people develop their own opinions and perceptions during the process of interaction with other people, that is, they are influenced, and they also influence. Therefore, this group should receive appropriate stimuli for the debate (KITZINGER; BARBOUR, 1999).

This research technique is characterized as qualitative, which seeks to create opportunities to analyze the individual beliefs, values, conflicts, confrontations, attitudes, preferences, needs and feelings (RESSEL et al., 2008). So, the procedure was the application of a single focus group, lasting I hour and I I minutes and the number of participants followed guidance studies about the focus group, referring 6 to I5 people as a recommended module (RESSEL et al., 2008); so, we used 8 people. The characterization of the participants of the focus group can be seen in Table I. In view of the confidentiality clause of the data collection, the participants will be called by codenames.

To conduct the focus group, we developed a protocol as a semi-structured interview, using the status consumption framework proposed by Strehlau and Aranha (2004) as base. The questions were used just as a reference when the group was not self-taught. In addition, we had some methodological cares in the conduction of the focus group. First, we explained the rules as proposed by Oliveira et al. (2008). We recorded the audio, and all the participants 
TABLE 1 - Demographic profile $(n=8)$

\begin{tabular}{|c|c|c|c|}
\hline Codename & Gender & Age & Education \\
\hline A & Male & 21 & Undergraduate \\
\hline B & Male & 23 & Undergraduate \\
\hline C & Male & 25 & Undergraduate \\
\hline D & Male & 21 & High School \\
\hline E & Male & 33 & Graduate \\
\hline$F$ & Female & 23 & Undergraduate \\
\hline $\mathrm{G}$ & Female & 21 & Undergraduate \\
\hline $\mathrm{H}$ & Female & 20 & Undergraduate \\
\hline
\end{tabular}

Source: author's analysis based on survey data.

agreed upon an authorization form. For data analysis, the material was transcribed in speech and body language (like, dislike, exalted voice, animation...). These data had initially a hybrid format. So, we grouped in words and proceed a content analysis.

\section{RESULTS}

The analysis of the status consumption behavior starts with the presentation of the survey data (see Table 2). The status consumption scale includes not just the status, but also it includes the analysis of

TABLE 2 - Status consumption analysis $(n=548)$

\begin{tabular}{|c|c|c|}
\hline & Mean & Standard Deviation \\
\hline Status $(\alpha=0.808)$ & 2.45 & 0.713 \\
\hline I am interested in new products with status. & 2.76 & 1.099 \\
\hline I would pay more for a product with status. & 2.52 & 1.088 \\
\hline I would buy a product just because it has status. & 2.09 & 1.013 \\
\hline The status of a product is relevant to me. & 2.76 & 1.129 \\
\hline A product is more valuable to me if it has some snob appeal. & 2.14 & 1.107 \\
\hline Sociability $(\alpha=0.735)$ & 3.93 & 0.687 \\
\hline I used to enjoy social events. & 3.76 & 1.008 \\
\hline I like to be surrounded by people. & 3.90 & 1.005 \\
\hline I consider myself a very sociable person. & 3.83 & 1.052 \\
\hline I enjoy hanging out with my friends. & 3.97 & 0.909 \\
\hline I like to meet new people. & 4.24 & 0.955 \\
\hline Functionality $(\alpha=0.685)$ & 2.56 & 0.741 \\
\hline I used to spend money with unpractical products. & 2.70 & 1.054 \\
\hline It is not silly to buy products that are unpractical. & 2.79 & 1.070 \\
\hline I buy products without functional purpose. & 2.43 & 0.986 \\
\hline I am used to buy products without functional reasons. & 2.35 & 1.023 \\
\hline
\end{tabular}

Source: authors' calculations based on survey data. Reliability is estimated through Cronbach's alpha. 
sociability and functionality of products, as proposed by Strehlau and Aranha (2004).

Analyzing these results, we can observe that, different that we expected, status consumption is not a strong behavior in the sample. Most respondents show that they did not look for status or for products without functionality. On the other hand, we observe a high level of sociability.

Some studies found that materialistic people use their assets to create their identity and thus to be accepted and admired in society (DITTMAR et al., 2007). In that way, previous studies explain that young people are sensible to social pressures, and as consequence, they believe to be accepted we must "have" and not "be" (CHIA, 20I0).

Using some profile characteristics to explain status consumption, through a Oneway Anova we found that there is only a statistic difference (sig. 0.03) between woman and men in status dimension, which man show that they are more status-oriented that woman.

Considering that these results denied generalizations widely known - that younger generations are more inclined to status consumption, we conducted a focus group with 8 young adults, which allowed to understand why we have negative responses in the first step of the research. In the beginning of the focus group none of the participants accepted the condition to be consumptive, especially when referring to products that afford status. However, during secondary discussions using the background of luxury, status, and conspicuous consumption, it was possible to identify that the matter was to assume that the purpose of their consumption was a way to earn social distinction - which potentially explains the results in the survey analysis.

First, we looked for the perceived so- ciability of the group. The group proved to be heterogeneous, being that some consider themselves more sociable than others, and because of this, we separate they into two subgroups. The first subgroup can be considered very sociable in the way that members love to attend parties and social events. The second subgroup can be considered less sociable and prefers long-term relationships, has small groups of friends and does not like to attend parties or social events. However, these differences of behavior do not reflect a different opinion about the status consumption.

About functionality, all respondents reported that they have already bought products they never used. On the other hand, we ask if they had already bought some products just for status. This issue clearly generated discomfort to the participants, who tried to explain why they already had status consumption. Some reactions for this question were:

I bought my IPhone just because all my friends have. (...) But I didn't considered as status consumption because I just like the brand'. (Part. G)

'I am used to buy some status products like shoes, but just because these brands have better quality'. (Part. H)

'I love Samsung because of the quality: my TV is Samsung; my laptop is Samsung and my smartphone is too.' (Part. B)

This behavior shows that unconsciously they did not think that they bought these products as a status consumption, but in the common opinion, they just did a good deal, or the product had better performance or quality. They report products as laptops, clothes, smartphones and tourism experiences, as some status consumption that they already had.

The brand issue was reported several 
times in the focus group. Even they do not consider themselves as people who consume by status, they reported that they usually notice the brands of the products that other people use, like cars, smartphones, and clothes.About brands, they also report that they can pay more for these products.

'I paid more on my IPhone because I bought on pre-sale.' (Part. F)

I bought the last version of Dell's laptop because I need a good functionality to develop my undergraduate activities'. (Part. C)

The participants agreed that the status consumption is very common and that young adults do it.They explained that these people buy to appear to be well-succeeded.This behavior is common in both genders, but the respondents understood that the products are different: "men like cars and technology and women like clothes and makeup".

However, during the discussion, respondents show that they are interested in buying some status products, but if they provide "experiences". As an example, we reported some listed experiences:

'I love artisanal beers. So, I pay more. (...) I do not consider myself consumerist with clothes, but in hanging out with friends I am.' (Part. B)

'For me, status will be going to Black Sabbath (rock concert) this November/December.'(Part. E)

I like to travel. When I am traveling, I feel fulfilled.' (Part. F)

'I have already sold some goods to travel.' (Part. E)

I save my money to spend traveling.'(Part. C) 'Last summer I went with some friends to Balneario Camboriú city and I closed a VIP area at the Shed nightclub... I spent a lot of money!' (Part. B)

So, the status consumption seems a rep- rehensible behavior, and maybe because of this, only a few assume that buy goods and services based on this attribute. But, talking about experiences focused on services, the participants of focus group completely changed the speech, and listed status consumption, like travels, parties, and some special products as artisanal beers.

\section{DISCUSSION AND IMPLICATIONS}

These results can be analyzed as a new insight about status consumption in Brazil: young adults are not worried about goods, but about experiences (services basically) and for these, they are able, and they want to pay more. In this way, we have two important contributions with theory. First, for status consumers, price is commonly used as an indicator of quality and exclusivity so as proposed by Dubois and Duquesne (I993), as well as, this segment enjoys paying higher prices for the social desire to stand out from the crowd or display wealth and status (AMALDOSS; JAIN, 2005).

About the "experiences", we found some literature in Dunn et al. (200I) who explain that people are often happier when they spend their money on experiences rather than things. Also, there are some evidences of this behavior in Van Boven and Gilovich (2003) who defined experiential purchases as those "made with the primary intention of acquiring a life experience: an event or series of events that one lives through" ( $p$. II94), so as those reported in our study.

Second, we found that Brazilian young adults do not like to be recognize as status consumers, even they were. They prefer to think that they consume just because these products have better quality or because the brand image. Literature explain this behavior, in which consumers purchase an ex- 
pensive wine, as example, not due to quality perceptions, but on their perception that others will perceive the high price as reflecting the internal traits of the purchaser (LICHTENSTEIN et al., 1993).

Also, our findings also show that Brazilian young adults are strongly influenced by brand image and quality. Several times these characteristics were described as the main issues that motivate the decision maker to buy luxury products. So, as supposed by Strehlau e Aranha (2004), there is a tangible component (quality) and an intangible component (brand) related on status consumption. This is a relevant result, considering that some luxury brands are looking to reduce production costs and it can be a trouble to customers' satisfaction and loyalty if these brands do not invest in quality.

Marketers from companies that would entry in the luxury segment in emerging countries like Brazil, should think local, especially if the public are young adults. The status segment, even the young adults do not accept it consumption as status consumption as we observe in the first study proceed in this paper, is an increasing behavior. But products and desires are different in every country, and so, marketers need to adopt 'glocalization strategies', as showed in other studies (SUN et al., 20 I6). So, local adaptation requires that 'managers understand how consumers attach value to products and services in local markets' (OVERBY et al., 2005, p. 140). Subsequently, companies should place its products as a social distinction good, but not as status consumption.

\section{CONCLUSIONS}

The status consumption phenomenon study with Brazilians young adults proved to be more complex than we supposed. First, seeking to describe how this phe- nomenon happen in this specific group, we performed a survey with 548 Brazilians - where the results showed low levels of consumption motivated by status.

Considering that these results denied generalizations widely known - that younger generations are more inclined to status consumption, we conducted a focus group with 8 young adults, which allowed to understand why we have negative responses in the first step of the research. We identify status consumption behavior with Brazilian young adults, as well as, we were able to understand that status consumption-oriented is not only related to goods, but to 'experiences' - which brought an important contribution to the literature on status consumption in young Brazilians and raised an important research question for future studies.

Finally, we could list the motivations driving young consumers to have status consumption in Brazil, that are: (I) high social recognition function; and (2) consumption driven by a tangible component (quality) and an intangible component (brand). So, this study provides foundation for organizations that operate in this segment - like, data to develop subtle marketing strategies, sophisticated and constantly adjustable - for the Brazilian young adults.

\section{Limitations and Future Research}

One limitation of the study is that the sample in both studies have high educational degrees and the average of age shows younger people. Future research should use new ways to analyze the status consumption, considering that people do not like to admit status consumption behavior. Also, new studies can look the phenomenon on different ethnic groups between the young adults, based on common language, or ancestral, or social, or cultural, or national experiences. 


\section{REFERÊNCIAS}

ALMEIDA, G. T.; ITUASSU, C. T.; MOURA, L. R. C. O sentido do consumo para membros das gerações X, Y e Z. Revista Ciências Administrativas, v.22, n.2, p.605-636, 2016.

AMALDOSS,W.; JAIN, S. Conspicuous consumption and sophisticated thinking, Management Science, v.5I, p. 10, p. 1449-1466, 2005.

BAKER, M. J. Selecting a Research Methodology. The Marketing Review, Westburn Publishers Ltda., 200I, p. 373-397.

BERRY, C. The Idea of Luxury: A conceptual and historical investigation. New York: Cambridge University Press, 1994.

CARVALHO, T. C.; MESQUITA, J. M. C. de. Aspectos Influentes na Decisão de Compra de Bens de Luxo: Estudo do Comportamento do Consumidor de Alta Renda de Belo Horizonte. Revista Gestão \& Tecnologia, Pedro Leopoldo, v. 9, n. 2, p. I-18, ago./dez. 2009.

CHIA, S. C. How social influence mediates media effects on adolescents' materialism. Communication Research, v. 37, p. 3, p. 400-420, 2010.

COSTA, L. M. A.;VASCONCELOS, E. G. S.; MAIA, M. R.A.; PALMEIRA, P. S.A.; LEITE, J. C. L. Consumo Conspícuo: Perspectiva de Fidelização do Consumidor LGBT no Setor de Turismo Brasileiro. Revista Hospitalidade, v. I5, n. 2, p. 83101, 2018.

COELHO, P.; ORSINI,A.; BRANDÃO, W.; PEREIRA, R. A Vulnerabilidade e o Consumo Conspícuo no Ritual de Formatura. Revista Interdisciplinar de Marketing, v. 7, n. I, p. 57-73, 2017.

DEETER-SCHMELZ, D.R; MOORE, J. N.; GOEBEL, D.J. Prestige Clothing Shopping by Consumers: A Con- firmatory Assessment and Refinement of the "Precon" Scale with Managerial Implications. Journal of Marketing Theory and Practice, v. 8, n. 4, p. 43-58, 2000.

DITTMAR, H.; LONG, K.; BOND, R. When a better self is only a button click away: Associations between materialistic values, emotional and identity-related buying motives, and compulsive buying tendency online. Journal of Social and Clinical Psychology, v.26, p. 334-36I, 2007.

DUBOIS, B.; DUQUESNE, P.The market for luxury goods: income versus culture. European Journal of Marketing, v.27, n. I, p.35-44, 1993.

EASTMAN, J. K.; GOLDSMITH, R.; FLYNN, L. Status consumption in consumer behavior: scale development and validation. Journal of Marketing Theory and Practice, v.7, n.3, p.4I-5I, 1999.

EASTMAN, J. K.; LIU, J.The impact of generational cohorts on status consumption: an exploratory look at generational cohort and demographics on status consumption. Journal of Consumer Marketing, v. 29, n.2, p.93-102, 2012.

FLYNN, L.R.; GOLDSMITH, R. E.; POLLITTE, W. Materialism, Status Consumption, and Market Involved Consumers. Psychology \& Marketing, v. 33, n. 9, p. 76I776, 2016.

HUSIC, M.; CICIC, M. Luxury consumption factors. Journal of Fashion Marketing and Management, $v$. I3, n. 2, p. 23|-45, 2009.

KASSER, T. Materialistic values, and goals. Annual Review of Psychology, v.67, p.489-5 I4, 2016)

KASTANAKIS, M.N.; BALABANIS, G.

Between the mass and the class: antecedents of the bandwagon luxury consumption behavior.
Journal of Business Research, v. 65, n. I0, I399-|407, 2012.

KIM, D.;JANG, S. Motivational drivers for status consumption:A study of Generation $Y$ consumers. International Journal of Hospitality Management, v. 38, p. 39-47, 2014.

KITZINGER J.; BARBOUR R.S. Introduction: the challenge and promise of focus groups. In: KITZINGER, J.; BARBOUR, R.S. (org.) Developing focus group research: politics, theory, and practice. London (UK): Sage; I999. p. I-20.

LICHTENSTEIN, D.R.; RIDGWAY, N.M.; NETEMEYER, R.G. Price perceptions and consumer shopping behavior: a field study. Journal of Marketing Research, $p$. 234-245, 1993

LUBECK, R. M., FALLAVENA, L. H.A., SANTINI, F. O., \& SAMPAIO, C. H. Diga-me no que andas e te direi quem és: aspectos de influência nos jovens da classe $C$ brasileira para adquirir automóveis. Revista Brasileira de Marketing, v. 13, n. 3, p. 17-35, 2014.

MARCOUX, J.S.; FILIATRAULT, P.; CHERON, E. The Attitudes Underlying Preferences of Young Urban Educated Polish Consumers Towards Products Made in Western Countries. Journal of International Consumer Marketing, v.9, n.4, p. 5-29, 1997.

NABI, N.; O'CASS, A. SIAHTIRI,V. Status consumption in newly emerging countries: The influence of personality traits and the mediating role of motivation to consume conspicuously. Journal of Retailing and Consumer Services, v.46, p. 173-178, 2019.

NIADA, A. C. M.; BAPTISTA, P. P. Hierarquia de metas do consumidor para diferentes níveis de autocon- 
exão com a marca: um estudo sobre a relação dos corredores de rua com a marca de seu tênis se corrida. Revista de Administração Mackenzie, v. 14, n. 5, p. |40- I76, 2013.

O'CASS, A.; FROST, H. Status brands: examining the effects of non-product-related brand associations on status and conspicuous consumption. Journal of Product and Brand Management, v.II, n.2, P. 67-88, 2002.

O'CASS, A.; SIAHTIRI, V. In search of status through brands from Western and Asian origins: examining the changing face of fashion clothing consumption in Chinese young adults. Journal of Retailing and Consumer Services, v.20, n.6, p.505-5I5, 2013.

OLIVEIRA, N.A.; PORTO,A.R.; PALMA, J.S.; CALCAGNO, N.G.S.; FEHN, L.A.C.; THOFEHRN, M.B. Contextualizando o grupo focal: Técnica de coleta de dados em pesquisa qualitativa. In: XVII Congresso de Iniciação Cientifica e $X$ Encontro de Pós-Graduação, 17, Pelotas-RS, Anais... Pelotas-RS, 2008.

OVERBY, J.W.; WOODRUFF, R.B.; GARDIAL, S.F. The influence of culture upon consumers' desired value perceptions: a research agenda. Marketing Theory, v.5, n.2, p. I39-163, 2005.

PASDIORA, M. A.; BREI, V. A. A formação do hábito de consumo infantil: uma análise crítica da Teoria de Consumo de Status aplicada às classes sociais altas e baixas no Brasil. Organizações \& Sociedade, v. 2I, n. 68, p. 789-8|4, 20 |4.

PAUL, P. Getting inside Gen Y, American Demographics, v.23, n.9, p.
42-49, 2001 .

PHAU, I.; CHEONG, E. How young adult consumers evaluate diffusion brands: effects of brand loyalty and status consumption. Journal of International Consumer Marketing, v. 2I, n. 2, P. 109-123, 2009.

PONTE, L. F.; MATTOSO, C. Q. Capital cultural e o consumo de produtos culturais: as estratégias de consumo de status entre mulheres da nova classe média. Revista Brasileira de Marketing, v. I3, n. 6, p. 18-33, 2014.

PRODANOV, C.C.; FREITAS, E. C. Metodologia do trabalho científico: Métodos e técnicas da pesquisa e do trabalho acadêmico. Novo Hamburgo: Feevale, 2009.

RESSEL, L.B.; BECK, C.L.C.; GUALDA, D.M.R. HOFFMANN, I.C.; SILVA, R.M.; SEHNEM, G.D. O uso do grupo focal em pesquisa qualitativa. Texto Contexto Enfermagem, v.17, n.4, p. 779-786, Out-Dez, 2008.

RICHINS, M. L. Social comparison and the idealized images of advertising. Journal of Consumer Research, v. I8, n. I, p. 7I-83, I99I.

RICHINS, M.L. Special possessions and the expression of material values. Journal of Consumer Research, v.2I, n.3, p. 522-533, 1994. ROBERTS, J.A.;TANNER, J. JR.; MANOLIS, C. Materialism and the Family Structure-Stress Relation. Journal of Consumer Psychology, v. I5, n. 2, p. I83-190, 2005.

SANTINI, F. O., LADEIRA,W. J., SAMPAIO, C. H., \& ARAÚJO, C. F. Percepção de Marca e Consumo Conspícuo: Análise do Efeito Moderador na Campanha Pro- mocional. Revista de Ciências da Administração, v. 18, n. 45, p. 38-52, 2016

SCHNEIDER, F;; KIRCHGASSNER, G. Financial and world economic crisis: what did economists contribute?. Public Choice, v. I40, n..3/4, p. 319-327, 2009.

STREHLAU, S.; ARANHA, F. Adaptação e validação da escala de Consumo de Status (SCS) para uso no contexto brasileiro. $\mathbf{R e}$ vista de Administração FACES Journal, v. 3, n. I, p. 9- I7, 2004. SUN, G.; D'ALESSANDRO, S.; JOHNSON, L.W. Exploring Luxury Value Perceptions in China: Direct and indirect effects. International Journal of Market Research, 2016 (in press).

TATZEL, M. 'Money worlds' and well-being:An integration of money dispositions, materialism and price related behavior. Journal of Economic Psychology, v.23, p. I03-126, 2002.

TRIGG, A.B. Veblen, Bourdieu, and status consumption. Journal of Economic Issues, v. 35, n.l, p. 99-II5, 2001.

VEBLEN, T. A teoria da classe ociosa: um estudo econômico das instituições. São Paulo: Abril Cultural, 1983.

VILAIN, J. S. B.; PEREIRA, M. F. O impacto do status no planejamento financeiro pessoal: estudo de caso com os advogados de Florianópolis, Santa Catarina. Revista Gestão \& Planejamento, v. | 4, n. 3, p. 470-488, 2013.

WHA - World Health Association. Division of Mental Health: Qualitative Research for Health Programs. Geneva/NY. 1994. 